\title{
The Histological Effect of Yaji Extract on Carbon Tetrachloride Induced Hepatotoxicity in Adult Wistar Rats
}

\author{
${ }^{1}$ Ezejindu D.N., ${ }^{2}$ Aligwekwe A. U. \\ ${ }^{I}$ Department of Anatomy, College of Health Sciences, Nnamdi Azikiwe University, Nnewi \\ ${ }^{2}$ Department of Anatomy, Madonna University, Elele, River State.
}

\begin{abstract}
Histological effects of yaji extract on carbon tetrachloride induced hepatotoxicity were studied using adult wistar rat. Twenty wistar rats weighing between 150-210g were used. They were designated into four groups of five animals each. Group A animals served as the control and received $0.6 \mathrm{ml}$ of distilled water. Group $B$ received $0.5 \mathrm{ml}$ of yaji extract, group $C$ received $0.3 \mathrm{ml}$ of carbon tetrachloride while group D received $0.5 \mathrm{ml}$ of yaji extract plus $0.3 \mathrm{ml}$ of carbon tetrachloride. The administration lasted for twenty-eight days using intubation method. Twenty-four hours after the last administration, the animals were weighed and sacrificed using chloroform. Liver tissue was collected, weighed and fixed in zenkers fluid for histological studies. The body weight of group $C$ animals were significantly higher $(P<0.001)$ than the control. The group D relative liver weight were statistically similar to the control. The photomicrograph of group A showed central vein that is centrally placed, group B showed central vein and sinusoids congested, no abnormality was seen, group C showed complete distortion of the cytoarchitecture of the liver, no hepatic cell nuclei are visible, hence hepatocellular necrosis. Group D photomicrograph showed mild fibrosis around the central vein, congested sinusoid in a background of hepatocellular hypertrophy.
\end{abstract}

\section{Introduction}

In Nigeria however, there is the growing concern about the excessive consumption of a meat sauce called 'yaji' which is used to serve the meat delicacy called 'suya' ${ }^{[1]}$.

Yaji is a complex mixture of spices and additives; its constituents are ginger, cloves, red pepper, black pepper, salt, white maggi (Ajinomoto) and groundnut powder; and their active ingredients on individual basis are known to be harmful if consumed in excess ${ }^{[2]}$.

Suya is a popular, traditionally processed, ready to eat Nigerian meat product, which may be served or sold along streets in club houses, at picnics, parties, restaurants and institutions. It is a consumer fast food whose preparation and sales along the streets are usually not done under strict hygienic conditions because they are still done locally ${ }^{[3]}$.

It identified as a mass consumer fast food whose preparation and sales along streets are usually not done under strict hygienic environment and can serve as source of contaminants to the meat product ${ }^{[4]}$. Suya as one of such intermediate moisture products that is easy to prepare and highly relished ${ }^{[5]}$.

Hepatotoxicity implies chemicals driven liver damage. Biochemical markers are often used to indicate liver damage. Liver damage is further characterized into hepatocellular and cholestatic types. Certain medicinal agents when taken in overdose and sometimes even when introduce within therapeutic range may cause liver injury. More than 900 drugs have been implicated in causing liver injury ${ }^{[6]}$, and it is the most common reason for drugs tobe withdrawn from the market. Other chemical agents (hepatotoxins) such as those used in the laboratories and industries, natural chemicals and herbal remedies can also induce hepatotoxicity. Chemicals often cause sub-clinical injury to the liver which manifest only as abnormal liver enzyme tests. Carbon tetrachloride $\left(\mathrm{CCl}_{4}\right)$ is a well known hepato-destructive agent that is widely used to induce toxic liver injury in a range of laboratory animals ${ }^{[7]}$. The hepatotoxicity of $\mathrm{CCl}_{4}$ has been reported to be due to its biotransformation by cytochrome $\mathrm{P} 450$ system to produce trichloromethyl free radical $\left(\mathrm{CCl}_{3}\right)$ which readily reacts with molecular oxygen to form trichloromethyl peroxy radical ${ }^{[8]}$. oxidation ${ }^{[9]}$.

$\mathrm{CCl}_{3} \mathrm{OO}$ which exert their action on lipids membrane of endoplasmic reticulum to evoke lipid per

Therefore, there is need to search, evaluate, and scientifically validate the activities of medicinal plants. The aim of this study is to evaluate the effect of yaji extract on carbon tetrachloride induced hepatotoxicity in the liver of adult wistar rats. 


\section{Preparation of constituents:}

\section{Materials And Method}

The measured quantities include: Ajinomoto (150g), Black pepper (30g), Clove (39), Ginger (78g) and Groundnut cake powder $(230 \mathrm{~g})$, Red pepper $(22 \mathrm{~g})$ and Salt $(100 \mathrm{~g})$. The total weight of these constituents summed up to $649 \mathrm{~g}$ in Nnewi area of Anambra state in the month of June, 2013.

\section{Aqueous Extract}

The constituents of yaji $649 \mathrm{~g}$ was grinded using a ginger grinder. The constituents were then macerated for $48 \mathrm{hrs}$ in $500 \mathrm{ml}$ of distilled water. The extract was strained through muslin and the filtrate then filtered through whatman No. 1 filter paper. The aqueous extract was concentrated on a rotary evaporator (Model type $349 / 2$ Corning Ltd., England). The extractive value of the aqueous extract was $250 \mathrm{mg} / \mathrm{ml}$.

\section{Animals}

Adult male wistar rats weighing 150-210g were obtained from the animal farm house, Department of Anatomy, Nnamdi Azikiwe University, Nnewi Campus. They were maintained under standard housing conditions and fed with standard rat chow (Growers mash) and provided with water ad libitum during the experiment. They were acclimatized for two weeks before the experiment.

\section{Experimental Design}

Twenty (20) albino rats were divided into four (4) groups (A-D) of five animals each. Group A received $0.6 \mathrm{ml}$ of distilled water, Group B received $0.5 \mathrm{ml}$ of yaji extract, Group C received $0.3 \mathrm{ml}$ of $\mathrm{CCl}_{4}$, Group D received $0.5 \mathrm{ml}$ of yaji extract plus $0.3 \mathrm{ml}$ of $\mathrm{CCl}_{4}$ and administration lasted for 28 days. All administration was by oral route. Twenty-four hours after the last administration, the animals were weighed and sacrificed using chloroform. Liver tissue was collected, weighed and fixed in zenker's fluid for histological studies.

\section{Statistical Analysis}

The results were expressed as mean \pm SEM. Difference between means was determined by the student t-test $\mathrm{p}<0.001$ was considered significant.

\section{Result}

The result obtained from calculation of initial, final and weight changes of the various groups are presented in table 1.

The final body weight for group $\mathrm{C}$ treated with carbon tetrachloride was significantly higher $(\mathrm{P}<0.001)$ than the control and other experimental groups $(\mathrm{B}$ and $\mathrm{D})$ animals. The weight change for group $\mathrm{C}$ showed a statistically increase compared with the control and other experimental groups $(\mathrm{P}<0.001)$.

Comparison of mean initial and final body weight and weight change in all the groups (A, B, C and D).

\begin{tabular}{|l|l|l|l|l|l|}
\multicolumn{2}{c}{ Table 1 } & Mean & \pm SEM given for each measurement) \\
\hline \multicolumn{1}{l|}{} & GROUP A & GROUP B & GROUP C & GROUP D & $\begin{array}{l}\text { PROBABILITY } \\
\text { SIGNIFICANC }\end{array}$ \\
\hline $\begin{array}{l}\text { INITIAL } \\
\text { BODY } \\
\text { WEIGHT }\end{array}$ & $100.00 \pm 3.48$ & $105.25 \pm 1.50$ & $160.25 \pm 6.32$ & $107.25 \pm 3.33$ & $<0.0001$ \\
\hline $\begin{array}{l}\text { FINAL } \\
\text { BODY } \\
\text { WEIGHT }\end{array}$ & $107.50 \pm 5.40$ & $116.00 \pm 8.27$ & $128.25 \pm 7.32$ & $116.50 \pm 9.45$ & $<0.0001$ \\
\hline $\begin{array}{l}\text { WEIGHT } \\
\text { CHANGE }\end{array}$ & $7.50 \pm 5.70$ & $10.75 \pm 5.03$ & $32.00 \pm 13.07$ & $9.25 \pm 4.50$ & $<0.0001$ \\
\hline
\end{tabular}

Figure 1 and 2 are the bar chat representation of the mean initial and final body weight. The weight of animals in group $\mathrm{C}$ were significantly higher $(\mathrm{P}<0.001)$ than group $\mathrm{A}$ (Control) and groups $\mathrm{B}$ and $\mathrm{D}$ before administration. After the administration, the weight of animals in group A (control) and group B and C increased statistically while the group D animals showed a significant decrease $(\mathrm{P}<0.001)$ compared to the weight before administration. 
Fig. 1

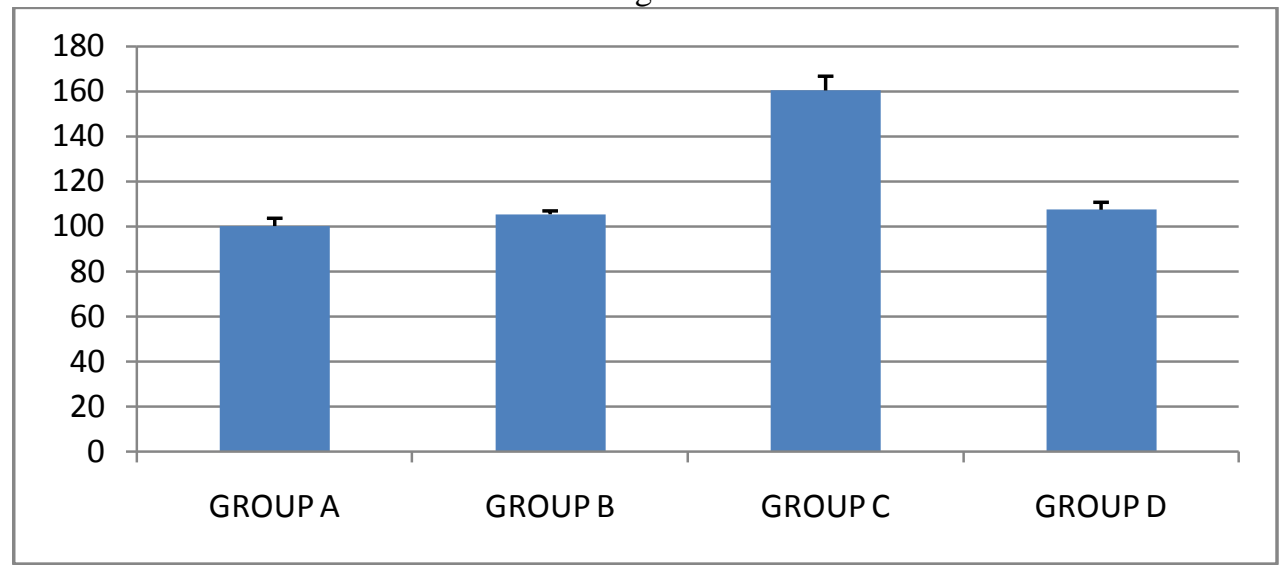

Weight of the animals before administration

Fig. 2

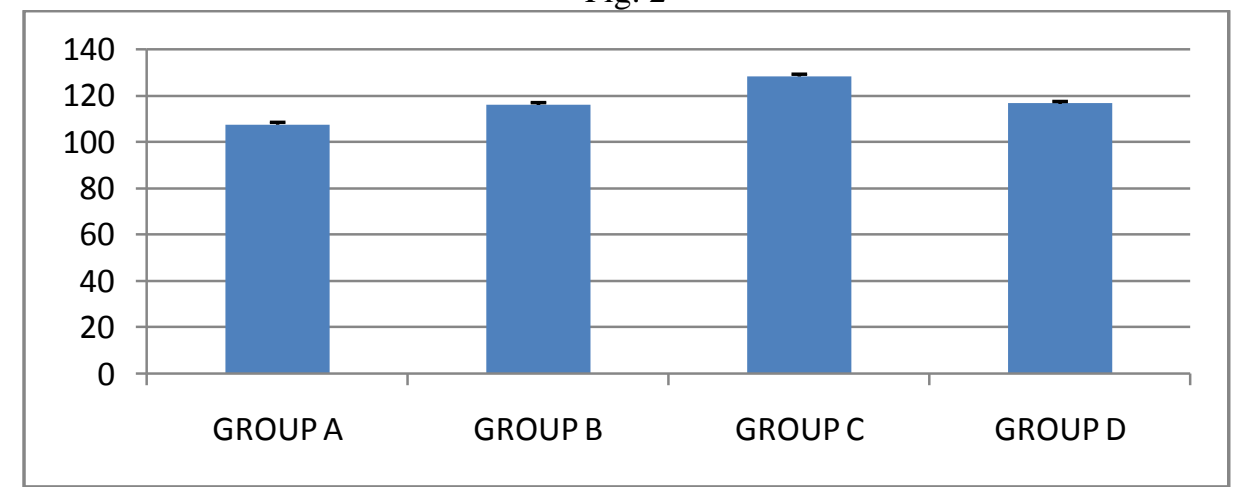

Weight of the animals after administration

\section{Morphometric Analysis Of Liver Weights}

The results obtained from calculations of relative liver weight of the various groups are presented in table 2. The relative liver weight for group $\mathrm{C}$ (carbon tetrachloride administered) were significantly higher $(\mathrm{P}<0.001)$ than that of the group $\mathrm{A}$ (control) and other experimental groups $(\mathrm{B}$ and $\mathrm{D})$. The values for groups $\mathrm{B}$ and D were similar to the group A, (control).

Comparison of mean relative liver weight for group A (control) and experimental groups (B, C and D)

Table 2 (Mean \pm SEM given for each measurement)

\begin{tabular}{|l|l|l|l|l|}
\hline & GROUP A & GROUP B & GROUP C & GROUP D \\
\hline LIVER WEIGHT & $4.90 \pm 0.045$ & $4.60 \pm 0.085$ & $7.23 \pm 0.625$ & $4.25 \pm 0.161$ \\
& & & & \\
\hline
\end{tabular}

The bar chart representation of the relative liver weight of the various groups. The group $\mathrm{C}$ (carbon tetrachloride administered) were significantly higher $(\mathrm{P}<0.001)$ than the control group $(\mathrm{A})$ and groups $\mathrm{B}$ and $\mathrm{D}$ as shown in Figure 3.

Fig. 3

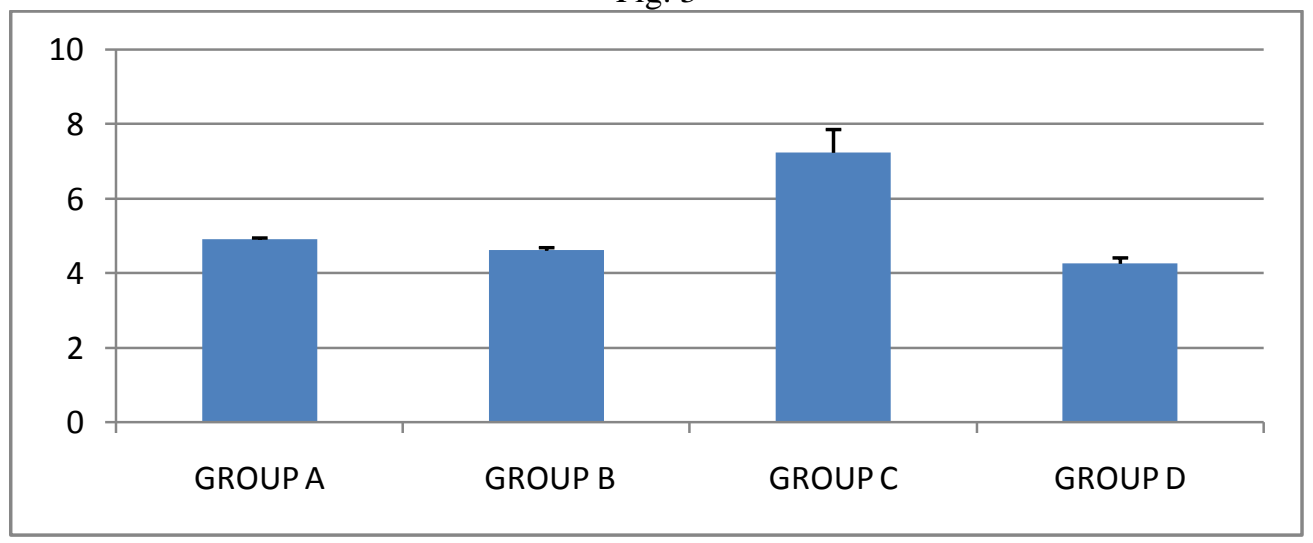

Relative liver weight of various groups 
Histological evaluation of liver of the animals confirmed the effects of yaji extract on carbon tetrachloride induced hepatotoxicity. Liver section of the group A showed that the central vein was centrally placed and no abnormality was seen (fig. A). Group B showed central vein and sinusoid congested, and no abnormality was seen (fig. B). Group C showed complete distortion of the cytoarchitecture of the liver, no hepatic cells are visible, hence hepatocellular necrosis (fig. C). Group D showed mild fibrous sinusoids around the central vein, congested sinusoids in a background of hepatocellular hypertrophy (fig. D).

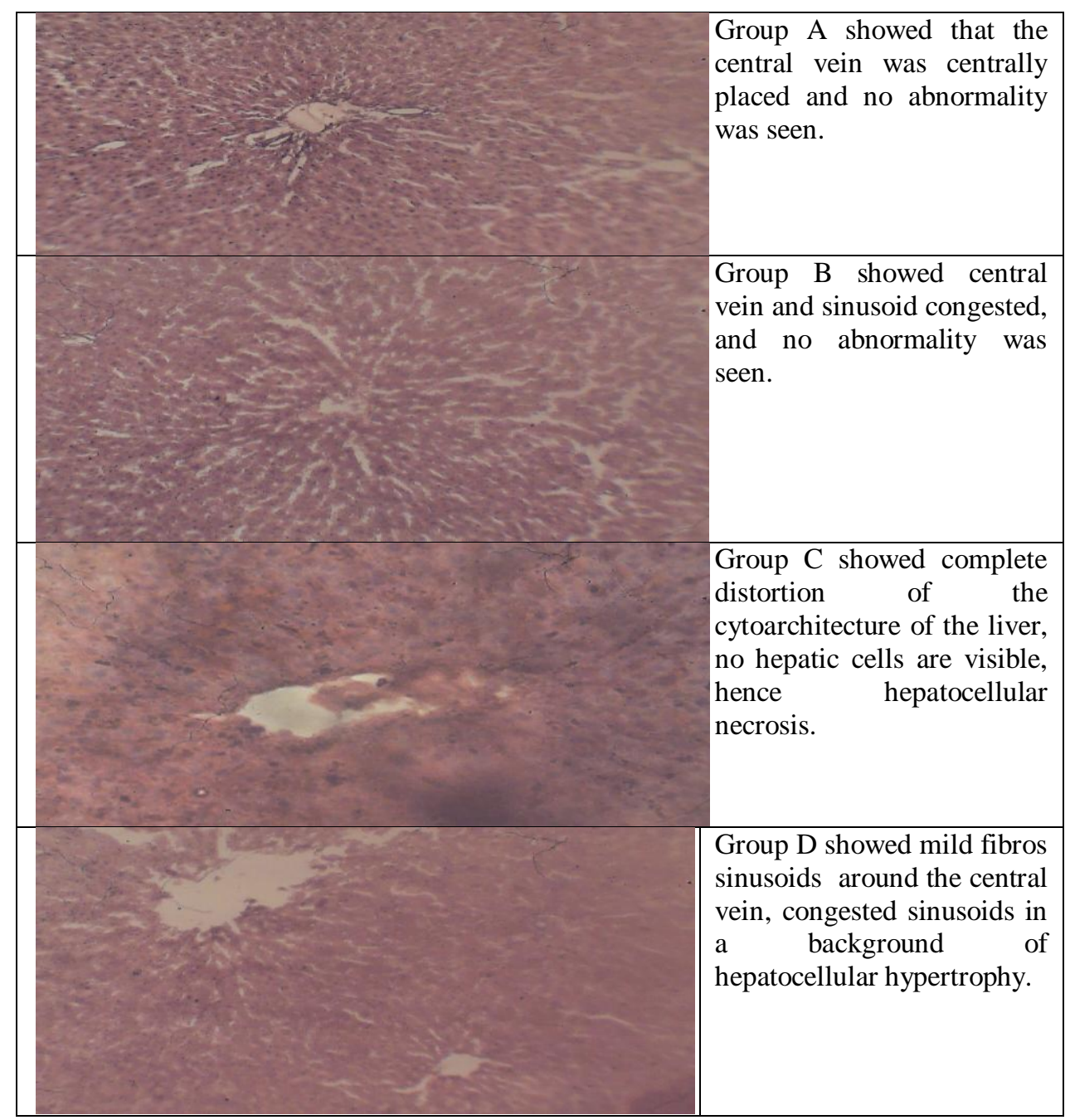

\section{Discussion}

Yaji is composed of the spices- ginger, clove, red pepper, black pepper, wh naggi (Ajinomoto) and salt which on individual basis are known to be harmful ${ }^{[2]}$. Some of the constituents exhibit antioxidant and hypolipidemic properties ${ }^{[10]}$. Others exhibit chemical, physiological and pharmacological properties and are also capable of inducing tissue damage ${ }^{[11]}$.

Our findings show that the extract has the potency to normalize the elevated liver marker enzyme levels and maintain the synthetic function of the liver when compared with the control.

This indicates restoration of the normal functional status of the liver. The significant elevations in the liver marker enzymes such as ALT, AST and ALP, in $\mathrm{CCl}_{4}$ control when compared with normal, suggest liver injury, since these are reliable indices of liver toxicity ${ }^{[12]}$. In liver damage, the synthetic capacity of the liver is reduced. The mechanism of $\mathrm{CCl}_{4}$ induced liver injury involves oxidative stress. Injury is through the free radical $\left(\mathrm{CCl}_{3}\right.$ and $\left.\mathrm{CCl}_{3} \mathrm{O0}\right)$ of its metabolism which may cause lipid peroxidation and subsequent injury ${ }^{[13]}$. Several studies on extraranal lesions, such as hepatic cirrhosis and myelofibrosis have reported a close correlation between mast cells and fibrosis ${ }^{[14]}$.

Histological observation showed that the administration of extract of yaji for 28 days, the hepatocytes were not distorted, there were no degenerated cells even when administered together with carbon tetrachloride showed distortion of the liver tissue. This means that carotenoid could not suppress the toxic effect of carbon 
tetrachloride administered for 28 days destroyed the cytoachitecture of the liver even when administered with carotenoid also cause damage to the liver tissues means that carbon tetrachloride in toxic to the liver.

From the present study, it has been proved that group D relative liver weight was statistically similar to the control. The photomicrograph of group A showed central vein that is centrally placed, group B showed central vein and sinusoids congested, no abnormality was seen, group $\mathrm{C}$ showed complete distortion of the cytoarchitecture of the liver, no hepatic cell nuclei are visible, hence hepatocellular necrosis. Group D photomicrograph showed mild fibrosis around the central vein, congested sinusoid in a background of hepatocellular hypertrophy.

\section{References}

[1]. Nwaopara, A.O., C.I.P. Anibeze and F.C. Akpuaka, (2010). Histological signs of neurodegeneration in the cerebrum of rats fed with diet containing Yaji: The complex Nigerian suya meat sauce. Asian J. Med. Sci., 2(1): 16 -21.

[2]. Nwaopara A.O, L.C. Anyanwu, C.A. Oyinbo, I.C. Anaikot, (2004). The histological changes in pancreas of wister rats fed with diets containing Yaji (Local meat sauce) .J. Exp. Clin. Anat., 3(2):44-47.

[3]. Igene JO, Mohammed ID (1983). Consumers' attitudes towards 'suya' meat product. Ann. Borno. 1. Retrieved 20th October, 2009 from http://www.pjbs.org/pjnonline/fin512.pdf.

[4]. Uzeh, R.E., R.E. Ohenhen and O.O. Adeniji, (2006). Bacterial contamination of tsire-suya, a nigerian meat product. Pak. J. Nutr., 5(5): 458-460.

[5]. Omojola AB (2008). Yield and organoleptic characteristics of Suya (an intermediate moisture meat) prepared from three different muscles of a matured bull African J. Biotech. 7(13): 2254-2257.

[6]. Friedman SE, Grendell JH, McQuaid KR (2003): Current diagnosis and treatment gastroenterology. Lang medical Books/ McGrawHill New York pp: 664-679.

[7]. Reyes-Gordillo K, Segovia J, Shibayama, M, Vergara, P, Moreno MG, Muriel P (2007): Curriculum protects against acute liver damage in the rats by inhibiting NF-KB, proinflammatory cytokines production and oxidative stress. Biochem Biophysics Acta. 1770: 989-996.

[8]. Raucy JL, Kraner JC, Lasker (1993): Bioactivation of halogenated hydrocarbons by cytochrome P450. EI. Grit Review of Toxicology 23:1-20.

[9]. Recknagel RO, Glende, EA, Dolk JA, Waller RL (1989):Mechanism of carbontetrachloride toxicity. Pharmacological Therapy 43 : $139-54$.

[10]. Manjunatha H, Srinivasan K (2008). Hypolipidemic and antioxidant potency of heat processed turmeric and red pepper in experimental Rats. Afr. J. Food Sci. 2: 1-6.

[11]. Govindarajan VS, Sathyanarayana MN (1991).Capsicum production, Technology, Chemistry and quality. Part V. Impact on physiology, pharmacology, nutrition and metabolism: structure, pungency, pain and desensitization sequences. Crit. Rev. Food Sci. Nutr. 29: 435-474.

[12]. Omoniyi KY, Matthew CI (2006): Protective effects of Zingiber officinale against carbon tetrachloride and acetaminophen-induced hepatotoxicity in rats. Phytotherapeutic Research. 20:997-1002.

[13]. Sies H (1997) : Oxidative stress: Oxidants and antioxidants. Experimental Physiology 82 (2): 291-295.

[14]. Eddy, A.A., (2001a). Mast cells find their way to the kidney. Kidney Int., 60: 375-377. 